\title{
Lipidoak aztertu eta identifikatzeko TLC kromatografiaren eta MALDI masa-espektrometriaren arteko akoplamendua
}

(Coupling TLC Chromatography and MALDI Mass Spectrometry for Lipids Analysis \& Identification)

Antonio Veloso

POLYMAT, Euskal Herriko Unibertsitatea UPV/EHU. Tolosa Hiribidea 72, 20018, Donostia antonio.veloso@polymat.eu

Laburpena: Geruza meheko kromatografia teknika (TLC, ingelesezko Thin Layer Chromatography) oso erabilia izan da hainbat molekularen banaketa eta karakterizaziorako. Bestalde, Matrix Assisted Laser Desorption Ionization Time of Flight Mass Spectrometry (MALDI-TOF MS) edo matrizez lagundutako laserraren bidezko desortzioionizazioa/hegaldi-denbora masa-espektrometria teknikaren erabilera gero eta gehiago hedatzen ari da molekula desberdinen analisia egiteko. Gainera, Imaging Mass Spectrometry (IMS) edo masa-espektrometriaren bidezko irudia izeneko teknikak, ahalbidetzen du ehun biologikoetan dauden lipidoen, proteinen eta farmakoen banaketa-irudiak lortzea eta teknika bikaina da molekula horien banaketa aztertzeko. Teknika honek lipido mota ezberdinen identifikazioa eta lokalizazioa ahalbidetzen du, konposatuaren edota familia kimikoaren aukera egin aurretik. Analizatu behar diren konposatuen aukera aldez aurretik egin behar ez denez, aukera dago irudiak sortzeko masa-espektrometroan detektatutako ioietatik abiatuta. Lan honetan, erakusten da lipidoen ikerkuntzarako oso lagungarria dela TLC xaflak eta MALDI IMS teknikak konbinatzea.

Hitz gakoak: MALDI, TLC, lipidoak, IMS.

Abstract: Thin Layer Chromatography (TLC) is a powerful technique to separate and characterize several molecules. On the other hand, nowadays the use of Matrix Assisted Laser Desorption Ionization Time of Flight Mass Spectrometry (MALDI-TOF 
MS) to identify molecules is increasing drastically. Besides, this technique allows to generate images by Imaging Mass Spectrometry (IMS). IMS is a perfect technique to analize the distribution of lipids in biological tissues. This technique allows the identification and localization of different lipids, without previous knowledge of the compound or chemical family. Since it is not neccesary to select the compound of interest before the MS acquisition, it is possible to generate images of each detected ion. In this work, TLC plates have been used to improve MALDI IMS. The combination of these techniques proves to be suited for lipid research.

Keywords: MALDI, TLC, lipids, IMS.

\section{SARRERA}

Azken urteetan, lipidoen ikerketak gora egin du eta masa-espektrometriaren (MS) garapenarekin batera, biomolekula hauen gaineko ezagumendua asko hazi da. Hori dela eta, lipidomika garaian gaudela esaten da. Bestalde, masa-espektrometria erabilita ioien masa/karga erlazioa $(\mathrm{m} / \mathrm{z})$ zehaztu daiteke. Lan honetan, zehazki Matrix Assisted Laser Desorption Ionization Time of Flight (MALDI-TOF) edo matrizez lagundutako laser desortzio-ionizazio hegaldi denbora masa-espektrometria erabiliko da lipidoak identifikatzeko lagin biologikoetan. Teknika honetan, lagina matrizearekin nahasten da eta espektrometroko laserrak laginean dauden osagai guztiak ionizatu egiten ditu laginean dauden osagai guztiak. Ondoren, ioiak euren masa/kargaren arabera, analizatzailean banatuko dira eta azkenik, ioiak detektagailura iritsiko eta espektro bat lortuko da. Espektroan dauden gailur guztiak, bat etorriko dira laginean dauden osagaien masa balioekin.

Beste alde batetik, egun, MALDI Imaging Mass Spectrometry (IMS) edo masa-espektrometriaren bidezko irudia deritzon teknikak, izenak dioen bezala, irudiak lortzea ahalbidetzen du. IMS teknika, oso teknika bikaina da ehun biologikoetan dauden molekulen banaketa aztertzeko. Teknika honek molekula mota ezberdinen identifikazioa eta lokalizazioa ahalbidetzen du, konposatuaren edota familia kimikoaren aukera egin aurretik. Analizatu behar diren konposatuen hautaketa aldez aurretik egin behar ez denez, aukera dago irudiak sortzeko, masa-espektrometroan detektatutako ioietatik abiatuta [1-3]. IMS teknikaren erabilera ehun edo materialen analisirako nahiko zuzena da eta software egokia edukiz gero, espezie ezberdinen banaketa erraz ikus daiteke. Ehun eta materialen arteko ezberdintasun bakarra dago: zein den analizatu nahi den gainazala. Halere, kasu bietan matrizez estalitako azalera analizatzen da, eta espektroak egiten dira, mikra gutxiko espazio-bereizmenean.

Lipidoak aztertzea lan konplexua da, espezie anitz daudelako zelularen ziklo metaboliko bakoitzean, eta kimikoki desberdinak izan arren euren masak oso antzekoak direlako. Beraz, gutxiengoan (erlatiboki kantitate 
txikietan) dauden espezieak detektatzeko ezinbestekoa da analisia egin aurretik lipidoen frakzionamendua edo banaketa egitea. Izan ere, lipido ugariz osatuta dauden lagin biologikoen eguneroko analisiak egiteko, denbora asko kontsumitzen dute eta deserosoak izaten dira lipidoak banatzeko dauden teknikak, esaterako, zutabeetan oinarritutako banaketak [4, 5], kolorimetriako teknikak [6,7], fluorometriakoak [8], eta detergenteetan disolbatzekoak disolbatzeak [9]. Azken urteetan, lipidoen analisien eraginkortasuna handitzeko, bi metodo garatu dira: Iatroscan kromatografia $[10,11]$ eta High Performance Liquid Chromatography (HPLC) edo bereizmen handiko kromatografia likidoa $[12,13]$. Iatroscan kromatografian edo Thin Layer Chromatography/Flame Ionization Detector (TLC/ FID) prozeduran, lipido-klaseak (espezieak) silikaz bustitako kuartzozko hagatxoetan banatzen eta detektatzen dira $[10,11]$. Metodo hau egokia da lipido neutroen azterketerako, baina desegokia lipido polarrak analizatzeko. Lipido neutro eta polar ohikoenak HPLC bitartez oso erraz banatzen dira, baina lipido mota asko daude eta oso zaila da teknika honen bitartez beraien estandarizazioa gauzatzea oso zaila da. Betidanik, lipidoak TLC edo geruza fineko kromatografia erabilita banatu izan dira [14]. Teknika hau laginaren osagai desberdinek disolbatzaile jakin batean duten higikortasunean oinarritzen da,

Horrela, konposatuok migratu egingo dute disolbatzailearekin bat egin eta aluminio edo beirazko azal batean zabalduta dagoen eta xurgatzailea den silikazko gelean edo beste edozein materialezko geruza mehe batean (silika gelezkoa gehienetan), eta lagineko osagaiak banatuko edo bereizi egingo dira.

Lan honetan, lipidoen banaketarako TLC teknika erabili da. Izan ere, teknika honek hainbat erraztasun eskaintzen ditu, azkarra da eta onartzen dituen disolbatzaileek banaketa sakon bat lortzea ahalbidetzen dute kasu gehienetan. Gainera, teknika sendoa, merkea eta oso ezaguna da, eta laborategi askotan erabiltzen da.

Lagineko osagaien eta disolbatzailearen arteko indar elektrostatikoak direla medio, elkarri gehiago edo gutxiago eragingo diote beraien arteko polaritatearen arabera, eta osagai bakoitzak gehiago edo gutxiago migratuko du xaflan zehar, altuera desberdin batera geratuta. Konposatuak identifikatzeko, TLC ereduzko teknikan, patroi ezagunak erabiltzen dira eta beraien fronte proportzioa $\left(\mathrm{R}_{\mathrm{F}}\right.$, ingelesezko ratio of front) konparatzen dira. $\mathrm{R}_{\mathrm{F}}$ parametroa, disolbatzaileen eraginez analitoak xaflan zehar abiapuntutik ibili duen distantzia bezala definitzen da. $\mathrm{R}_{\mathrm{F}}$-ak izan dezakeen gehienezko balioa 1 da, eta $\mathrm{R}_{\mathrm{F}}$-aren balio egokienak 0.55 eta 0.7 artekoak dira. Teknika honen bitartez, laginean dauden lipidoak modu erlatiboan baizik ezin dira kualifikatu; alegia, ez da zehazten zenbat eta zeintzuk diren lipido horiek, ez eta kate alifatikoen luzera eta asegabetasun kantitateak (karbono-karbono lotura bikoitzak). Aldiz, TLC-ri MALDI-TOF masa-espektrometria 
akoplatuz, banatutako lipidoak identifika daitezke, eta gainera, detektatutako lipido-espezieen kopurua emenda daiteke.

MALDI-TOF teknika erabilita, masa txikiko molekulak ezin dira ongi aztertu eta kontuan izanda lipido askok masa txikia daukatela, zaila da haien analisia MALDI-TOF bidez egitea. Gainera, MALDI-n maiz sortzen dira metal alkalinoen aduktuak. Ondorioz, espezie isobarikoen (hau da, protoi edo neutroi kopuru desberdina duten masa bereko espezieen) kopurua erabat areagotzen da. Honekin batera, beraien propietate fisiko-kimikoak direla eta, lipido mota desberdinak detektatzen dira eta askotan ondo detektatzen diren espezieek oztopatu egiten dute horren ondo detektatzen ez diren lipidoen detekzioa, hau da, ioi-supresio deritzon efektua. Efektu hau minimizatzeko ezinbestekoa da osagaiak banatzea MS analisia egin aurretik. Lan honetan, proposatutako irtenbidea ondorengoa da: lehendabizi TLC bidez lipidoak banatzea eta TLC xaflan bertan, MALDI matrizea gehitzea eta ostean MALDI Imaging Mass Spectrometry (IMS) analisia egitea [1-3].

Artikulu honetan erakusten da nola aztertu den TLC eta MALDI konbinatuta garatutako teknikak lipidomikan duten baliagarritasuna. Horretarako, TLC-MALDI teknikaren bitartez, erauzkin batetik banatu diren lipido espezie desberdinak analizatu, talde bakoitzeko espektroak lortu eta laginean dauden lipido espezie desberdinak identifikatu dira. Gainera, lipido espezie edo mota desberdinak ez dira modu berean ionizatzen teknika honen bitartez. Horregatik, ehun baten erauzkina analizatzen denean, gehien ionizatzen diren espezieek eragotzi egiten dute beste lipido espezieen detekzioa. TLC-IMS teknika erabilita, arazo honi konponbidea ematen zaio.

IMS teknikaren erabilera TLC esperimentuen analisirako nahiko zuzena da eta software egokia edukiz gero, espezie desberdinen banaketa erraz ikus daiteke. Ehun eta TLC-ren arteko desberdintasun bakarra dago: zein den analizatu nahi den gainazala. Halere, kasu bietan matrizez estalitako azalera analizatzen da, espektroak eginez, mikra gutxiko bereizmen espazialean. TLCa eta IMSa akoplatzeko dauden programa informatikoen helburu nagusia da espektroak jasotzea, lerrokatzea eta kalibratzea. Horrez gain, identifikatzeko eta kromatografiaz banatu diren lipido mota desberdinen batezbesteko espektroak lortzeko ere erabil daitezke.

\section{METODOAK}

\subsection{TLC kromatografia}

\subsubsection{TLC xaflaren tratamendua}

Silika gel G-25 materialaz estalitako $50 \times 75 \mathrm{~mm}^{2}$-ko TLC xaflak (Scharlau) erabili dira. TLC xaflak berogailu batean $100^{\circ} \mathrm{C}$-an 20 minutuz deshidratatu dira. Laginak xaflaren ertz batetik $1 \mathrm{~mm}$-ra ziztatu dira. TLC 
bitarteko lipidoak banatzeko, disolbatzaile-sistema ezberdinez osatutako bi metodo erabili dira. Kasu bietan, kubetak disolbatzailez altuera finko batera betetzen dira eta ondoren, ase direnean bertan TLC xafla sartzen da. Horretarako, disolbatzaile-nahastearen $15 \mathrm{ml}$ gehitu dira eta 10 minutuz itxita mantendu dira kubeta disolbatzaile sistemaren lurrunez asetzeko.

\subsubsection{Lipidoen banaketa TLC erabilita}

Lipidoak banatzeko lehen metodoan 5 disolbatzaile-sistema erabili dira, eta gainera, TLC xaflak disolbatzaile hauetan busti aurretik, 1 mM EDTA pH 5-5.5-ean bustitzen dira. EDTA-z bustitako TLC xafla, lehenengo kubetan sartzen da. Honek kloroformo-metanol-ura 65:40:5 $(v / v / v)$ erlazioan dauka eta disolbatzaileak $2 \mathrm{~cm}$ egiten ditu gora xaflan zehar. Bigarren kubetan, etil azetato-isopropanol-etanol-kloroformo-metanol-\%0.25 KCl 35:5:20:22:15:9 $(v / v / v / v / v)$ nahastea dago eta $3.5 \mathrm{~cm}$-ra mantentzen da. Gero, tolueno-dietil eter-etanol 60:40:3 ( $v / v / v)$ sartzen da $6 \mathrm{~cm}$-raino; 4. kubetan $n$-heptano-dietil eter 94:8 $(v / v) 6.5 \mathrm{~cm}$-ra igotzen da; azken kubetan, $n$-heptanoz betetakoak, $7 \mathrm{~cm}$ egingo du gora, disolbatzaileak ezpurutasunak xaflatik kanpo eramateko [15] (1. irudia). Banaketa metodo honen bidez, polaritate baxuko 5 li-

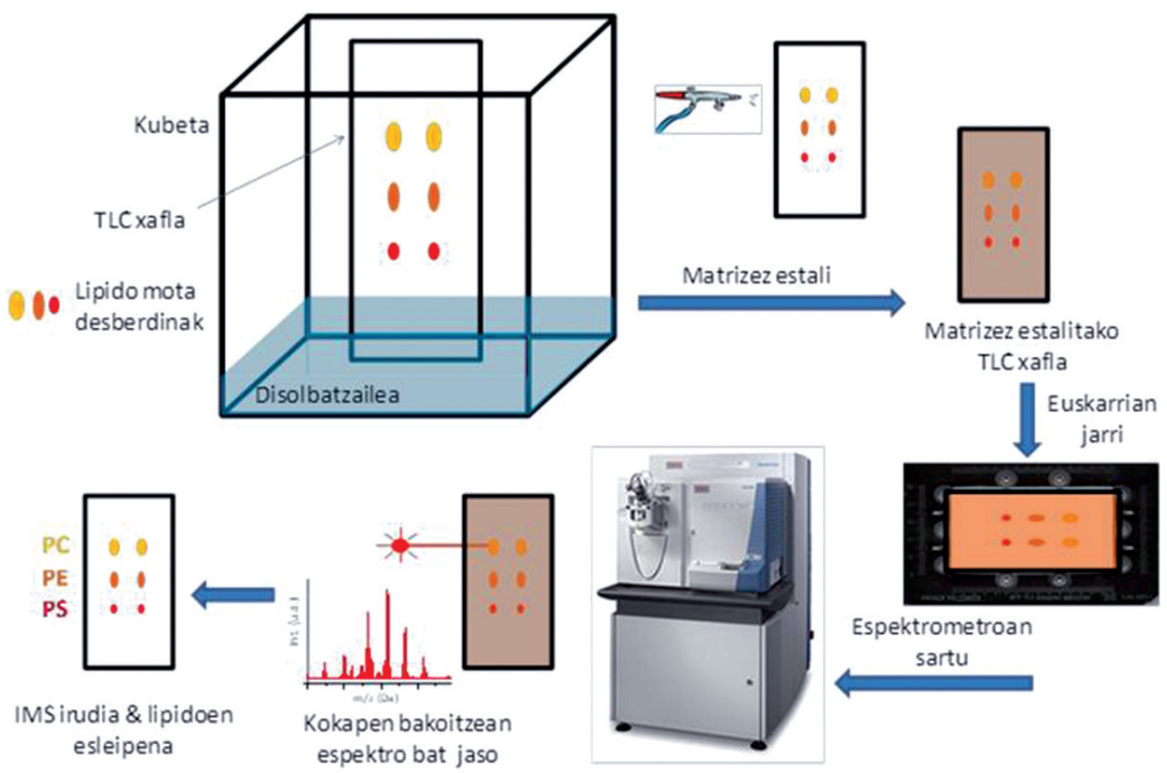

1. irudia. TLC kromatografia eta MALDI IMS teknikak akoplatzeko eskema: Kubetan TLC xafla sartzen da eta lipido mota desberdinak polaritatearen arabera banatzen dira. Ondoren, TLC xafla matrizez estaltzen da eta euskarrian jartzen da espektrometroan sartzeko. Espektrometroa programatzen da eta TLC xaflaren posizio bakoitzean espektro bat jasotzen da. Espektro guztiak izanda IMS irudia lortzen da eta lipido espezie bakoitzaren esleipena. 
pido espezie banatzen dira: ester kolesterolak (CE), triazilglizerolak (TAG), diazilglizerolak (DAG), kolesterol askea (FC) eta gantz azido askeak (FFA). Gainera, fosfolipido mota desberdinak banatzen dira: kardiolipinak (CL), fosfatidiletanolaminak (PE), fosfatidilinositolak (PI), fosfatidilserinak (PS), esfingomielinak (SM) eta lisofosfatidilkolinak (LPC).

IMS esperimentuekin konparatzeko ondoz ondoko xaflak errebelatzen dira. Honetarako xaflak urperatu egiten dira 10 segundo \% 10 sulfato kuprikoa eta \% 8 azido fosforikoa duen uretan [16]. Gero, ile-lehorgailua erabilita, xafla lehortzen da aire beroarekin lipidoen orbanak agerian agertu arte; jarraian xafla berotzen da 2 minutuz $200^{\circ} \mathrm{C}$-ra.

\subsection{MALDI-TOF masa-espektrometria}

\subsubsection{Matrizearen aukeraketa}

TLC-n banatutako lipidoak MS-z detektatzeko disolbatutako matrize egokiena hautatu da, hots, lipido espezie gehien detektatzea ahalbidetzen duen matrizea. Horretarako, lipidomikan ohikoak diren bost matrize desberdin probatu dira: 2-merkaptobenzotiazola (MBT), 9-aminoakridina (9AA), azido $\alpha$-zianohidroxizinamikoa (CHCA), azido 2,5-dihidroxibenzoikoa (DHB) eta ditranola.

Matrize egokia aukeratutakoan, TLC xaflen gainean homogeneoki jartzen da, xaflan bertan banatuta dauden lipido espezieak barreiatzen ez direla ziurtatuz. Matrizea uniformeki zabalduta izan eta emaitzen errepikakortasuna gertatu behar da. Matrizez estali aurretik, ultramore-lanpara (UM) baten azpian arkatzez lipidoak dauden orbanak seinalatzen dira. Askotan lerroak ere egiten dira espektrometro barruan gidari bezala erabiltzeko. Horrela, IMS esperimentua egin aurretik orban batzuen gainean laser-tiroa egiten da eta espektro on bat lortu arte optimizatzen dira parametroak, hala nola, energia, tiroa zenbakia, maiztasuna, masa-eskualdea, detektorea, etab.

\subsubsection{TLC xafla matrizez estaltzeko metodoa}

TLC xafla matrizez estaltzeko lau metodo probatu dira. Hasteko, matrizez asetutako disoluzioaren mikrolitro bat pipeta bidez zuzenean jartzen da, baina lipidoen migrazioa gertatzen da; beraz, ezin izan da teknika hau erabili. Ondoren, espraiatzea probatu da. Honetarako, espraiatzailea (DESAGA Starsted-Gruppe SG1) erabili eta matrizez asetutako $20 \mathrm{ml}$ disoluzio jartzen dira xaflan. Gero, matrizea aldika gehitzen da, 3 minutuan behin ordubetez, xafla homogeneoki busti arte. Hurrengo metodoa murgilketa izan da. $20 \mathrm{ml}$ matrizez asetutako disoluzioa prestatu eta Petri xafla batean jartzen da. Matxarda batzuen laguntzaz, TLC xafla murgiltzen da 3 segundoz, xaflaren xurgatzaile aldea behera begira eta ontziaren hondoa 
ukitzea saihetsita. Xafla murgilketatik atera bezain laster, horizontal mantentzen da gantxo batzuen laguntzaz. Ile-lehorgailu batekin aire fluxu hotz eta leunean lehortzen da (2. irudia). Azkenik, sublimazioa probatu da. Honetarako sublimatzaile bat erabilita TLC xafla itsatsi egiten da nitrogeno likidoa dagoen aldearekin eta matrizea kontaktuan jartzen da berogailua dagoen aldearekin. TLC xafla matrizez estali ondoren, xafla euskarri metaliko berezi batean egokitzen da (3. irudia).
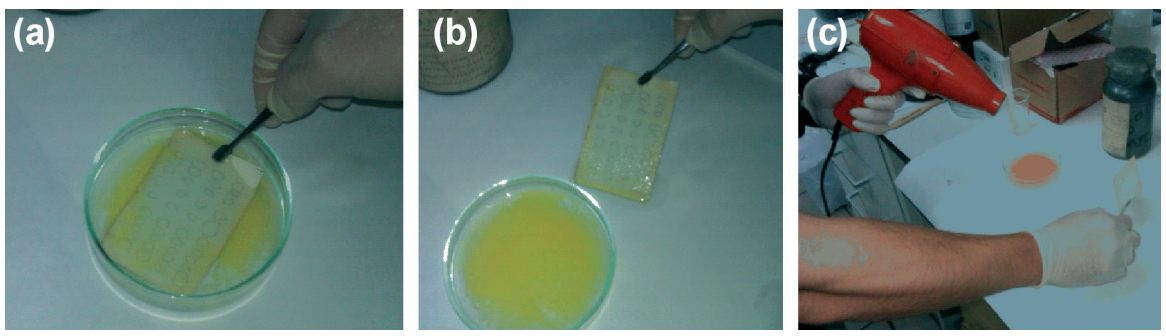

2. irudia. Murgilketaren prozedura. (a) TLC xaflaren murgilketa matrizez asetutako Petri xaflan. (b) Xafla kanporatzerakoan. (c) Xaflaren lehortzea.
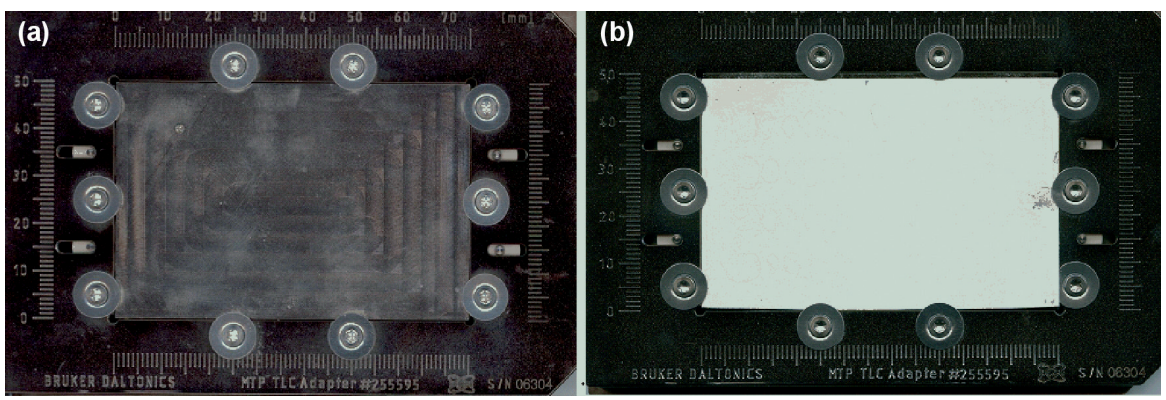

3. irudia. (a) TLC estandar $\left(50 \times 75 \mathrm{~mm}^{2}\right)$ MALDI-plaka euskarri metaliko berezia. (b) TLC xafla MBT matrizez estalita murgilketaren bidez, eta euskarri metalikoan egokituta.

\subsubsection{MS analisia}

TLC esperimentu osteko MS analisi guztiak Bruker IV MALDI masaespektrometroan (Bruker Daltonic) egin dira. MALDI teknikan, pausu oso garrantzitsua da aztergai dugun laginetik ioiak sortzea. Orokorrean, laserraren irradiazioa analito molekulen desortzio eta/edo ionizazioa egiteko erabiltzen da, eta, matrizea aldiz, energia-absortziorako bitartekari gisa. Irradiazio gertatzen denean, tentsio ezberdinak erabil daitezke katioiak edo anioiak sortzeko. Normalean, tentsioak aukeratzeko gure analitoaren egi- 
turari erreparatu behar diogu. Izan ere, talde batzuk errazago kationizatzen dira beste batzuk baino, eta alderantziz. Gure kasuan, erauzkin lipidikoetan, lipido batzuk erraz kationizatzen dira (fosfatidilkolinak adibidez) eta beste batzuk erraz anionizatzen dira (fosfatidilinositolak adibidez).

Espektroetan masa absolutu independenteen baloreak lortzen dira, eta beraz, horiek ondo ulertzeko lehendabizi beharrezkoa da MALDI espektrometroa kalibratzea. Era honetan, xaflan bertan kalibratzaile bat jartzen da, masa zehatzagoak edukitzeko. Espektro bateko gailurrek, argiak izateko $s / n$ erlazioa (ingelesezko signal to noise) egokia izan behar dute. $s / n$ erlazioa, transmititzen den seinalearen eta zarata-potentziaren arteko erlazio bezala definitzen da. Datuak programa informatiko baten bitartez analizatzeko, TLC-n lipido espezie bakoitzaren orbanaren irudia ikusiko da eta osagai nagusizko analisia egiten da (PCA, ingelesezko Principal Component Analysis), hau da, klusterren bidez lipido-espezie ezberdinak bereizten dituen analisi estadistikoa.

\section{EMAITZAK ETA EZTABAIDA}

\subsection{Matrizearen aukeraketa}

Lipidoak detektatzeko metodoen atalean aipatutako bost matrize probatu dira bi erreflektroi moduetan, negatibo (RN) eta positibo (RP). Erreflektroi-analizagailuaz masa hobeto bereiz daiteke, hau da, lortzen da ioi negatibo (modu negatiboan) eta positiboen (modu positiboan) gailurrak estuagoak izatea. Emaitza hoberenak bi matrize desberdinetan lortzen dira erreflektroi moduaren arabera: 9AA eta MBT matrizeetan hain zuzen ere. Zenbait ikerketa egin dira matrize hauen eraginkortasuna egiaztatzeko lipidoen analisian [17-20]. 4. irudian, 9AA erabilita egiaztatzen da lipido batzuk ondo detektatzen direla $\mathrm{RN}$ moduan, baina masa tarte finko eta oso txikian. Gainera, ez da lortzen lisofosfatidilkolinen (LPC), fosfatidilkolinen (PC), esfingomielinen (SM) eta fosfatidiletanolaminen (PE) seinalerik.

MBT matrizea erabiltzen denean, aldiz, espektro oso argiak lortzen dira RP moduan. Izan ere, $s / n$ erlazio hobeagoak izaten dira eta lipido espezie gehiago detektatzen dira. Horregatik, kasu honetan erakusten den espektro tartea askoz handiagoa da. Beste aldetik, RP-n grisez azpimarratutako eskualdearen handiagotzea konparatzen denean $\mathrm{RN}-\mathrm{n}$ lortutako espektroarekin, RP-n argi ikusten da gailur edo piku gehiago daudela, hau da, espezie gehiago detektatzen direla. Gailurren gainean zehazten da lipidoen esleipena, hau da, zeintzuk diren lipido espezieak eta zein den karbono (kate luzera) eta lotura bikoitzen kopurua. 

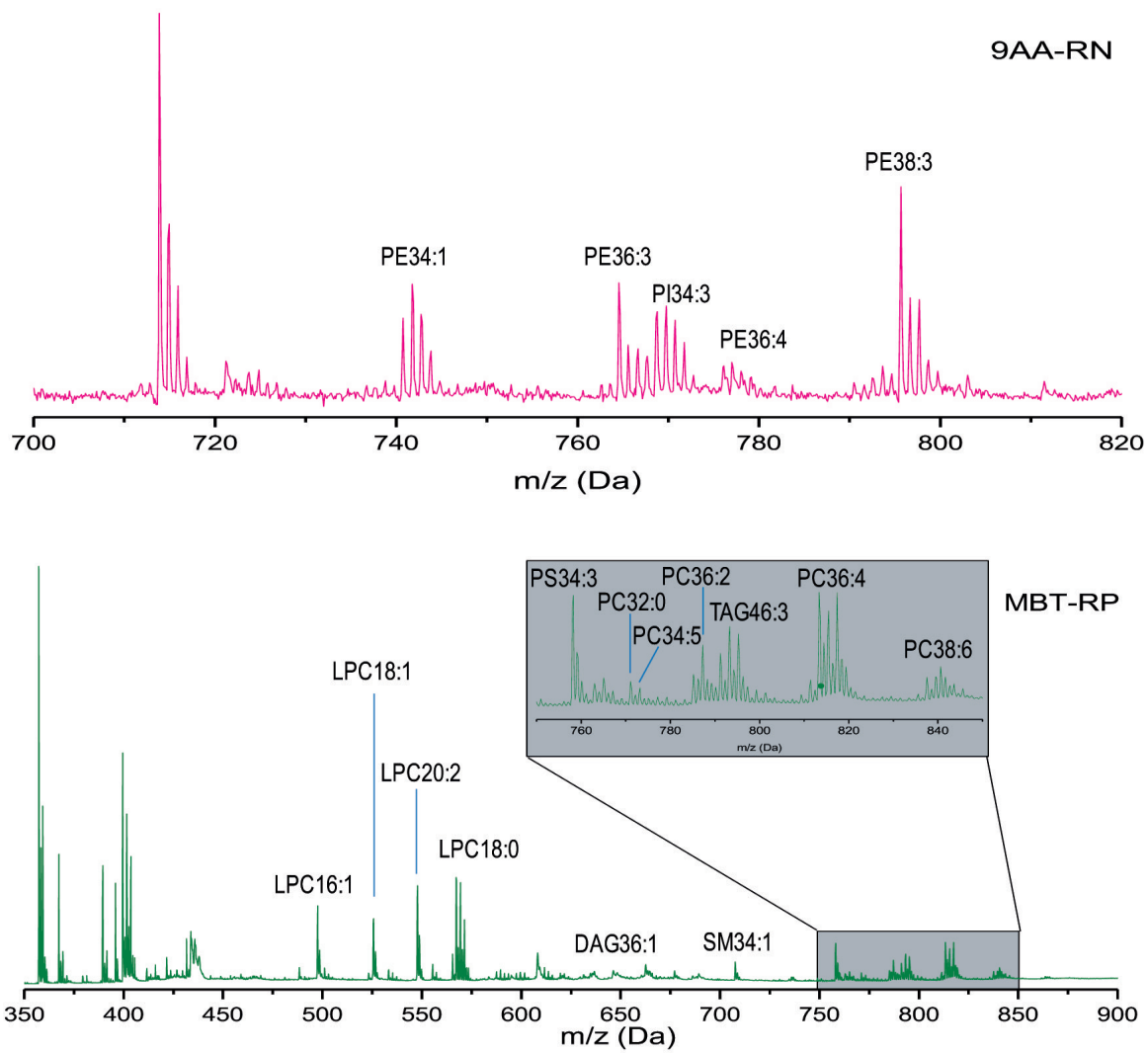

4. irudia. Erreflektroi negatibo moduan $(\mathrm{RN})$ eta 9AA matrizea erabilita lortutako espektroak TLC-MS esperimentu batean, 700-820 Da masa tartean (goian); erreflektroi positibo moduan (RP) eta MBT matrize erabilita lortutako espektroak 350-900 Da masa tartean (behean). Espektroaren handiagotze bat erakusten da grisez azpimarratutako eskualdean (750-850 Da masa bitartean).

\subsection{TLC xafla matrizez estaltzea}

Bi matrize hauek erabilita, TLC xafla estaltzeko aipatu diren 4 metodo probatu dira. Emaitzek erakusten dute teknika guztiek bermatzen dutela lipidoen detekzioa, baina alde batzuk daudela: espraia erabiliz, zailagoa da matrizearen banaketa homogeneoa gauzatzea. Gainera, prozesua luzeagoa denez, laginaren degradazioa gerta liteke. Murgilketa erabiliz, banaketa askoz homogeneagoa da, baina lipido batzuen migrazio gerta liteke. Sublimazioan, banaketarik homogeneoena lortzen da. Halere, matrize-geruza oso lehorra geratzen denez, laserra ezin da laginera ondo iritsi. Murgilketa erabiltzerakoan lipidoen intentsitate handiena lortzen denez, ikusi da murgilketa dela metodo egokiena. 
5. irudian erakusten da 9AA (A) eta MBT (B) matrizeak erabilita murgilketak TLC plaketan jasaten duen eraldaketa. MBT erabilitako xaflan matrizea askoz homogeneoagoa gelditzen da eta espektroak intentsitate askoz handiagoz lortzen dira. Horregatik, MBT matrizea RP moduan bakarrik erabili da erakutsiko diren ondorengo emaitzetan.

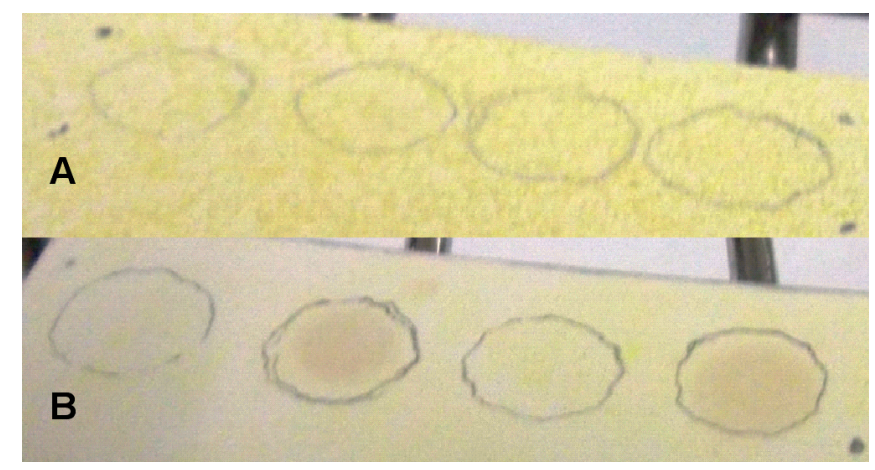

5. irudia. Optika-irudiak, patroi lipidikoak dituzten TLC plaketan bi matrize desberdinetan murgilketa egin ondoren: (A) 9AA eta (B) MBT.

\subsection{MS analisia}

Lortzen diren lipidoen masa zehatzagoak izateko, kalibratzaile baten analisia egin behar da TLC xaflan bertan. Kalibratzaileak lipidoak agertzen diren eskualde osoa bete behar du. Kasu honetan, polietilenglikol (PEG) bat aukeratu da. Horretarako, PEG jartzen da lipido isurbideen ondoan eta jarraian, TLC xafla matrizez estaltzen da murgilketa erabiliz.

Gure laborategian egindako TLC esperimentuen irudiak garatzeko softwarea probatzeko, laginetan egin aurretik, TLC xafla batean posizio jakin batzuetan bost patroi lipidiko desberdinak eta kalibratzailea jarri dira. Xafla, MBT-z estaltzen da murgilketa erabiliz. Lehortu eta gero, xafla euskarri metalikoan jarri eta masa-espektrometroan sartzen da. $250 \mu \mathrm{m}$-ko bereizmena ezartzen da $110 \times 7$ puntuko dimentsioan, hau da, 770 espektro, eta espektro bakoitzean laserraren batezbesteko 30 tiro egiten dira, \% 50eko -eko laser-potentzia erabilita RP moduan. Eskuraketa bukatu bezain laster, koordenatu bakoitzeko karpeta bat egiten da artxibo nahikoekin puntu bakoitzeko espektro bat berregiteko beste fitxategi sortuta. Gure laborategian, TLC-MS esperimentuen tratamendua egin daiteke bertan garatutako TLC-MALDI softwarea erabiliz. Hau da, espektroak taldeka biltzen (pilatzen) dira antzekotasunaren arabera edo espektroak gehitzen dira. 6. irudian ikusten da TLC-MALDI programa erabilita zazpi espektro talde desberdinak bereizten direla, TLC kale jakin batzuetan kokatuta. 


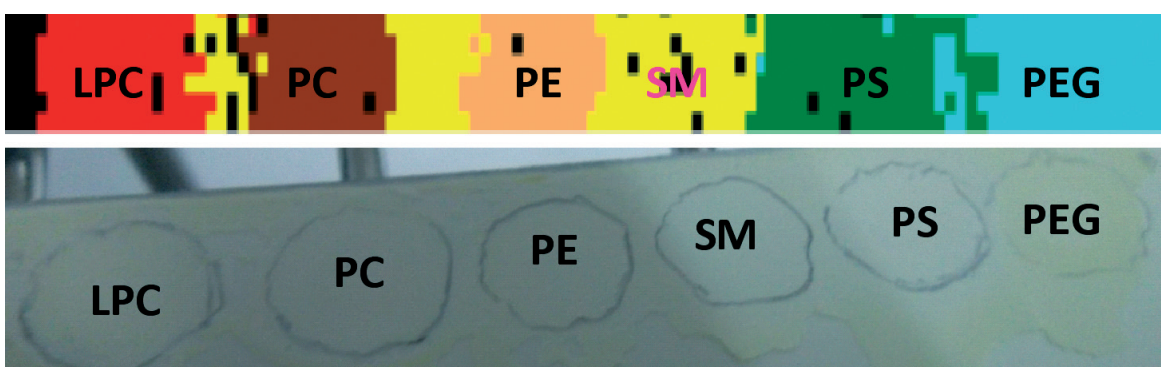

6. irudia. Goian, osagai nagusizko analisia (PCA) irudia, espektro-taldeak banatzen dira antzekotasunen bidez. Espezie bakoitza kolore desberdin batekin bereizten da. Behean, MBT-z estalitako eta eskaneatutako TLC isurbideko optika-irudia. Patroi lipidiko bakoitzaren orbana ikusten da arkatzez markatutako zirkuluan.

Espezie bakoitzeko espektroak TLC xaflan kokatuta daudenean, aukera dago batezbesteko espektroa lortzeko bereizten diren klusterretan; baita kluster bakoitza kokatzen den tokia ere (zuriz agertzen da eta atzealdea beltzez). 6. irudian, TLC xaflan espezie bakoitzeko klusterren batezbesteko espektroa agertzen da, alegia, aurreko esperimentuan lortutako PCA-ren analisia egin eta gero, garatutako softwareak kluster bakoitzaren kokapena (orbana) eta bere batezbesteko espektroa ikusteko aukera ematen du. Era honetan, 7. irudian lipido-patroi espezie desberdinen batezbesteko espektroak erakusten dira. Kasu honetan behetik hasita ikusten diren orbanak: lisofosfatidilkolinak (LPC), fosfatidilkolinak (PC), fosfatidiletanolaminak (PE), esfingomielinak (SM), fosfatidilserinak (PS) eta azkenik polietilenglikol (PEG) kalibratzailea. Espektro bat SM eta PE batuketari dagokio, lipido batzuk murgilketa eginda migratu edo barreiatu egiten baitira.

8. irudian, marraskari-burmuineko lipido-erauzkinaren TLC esperimentu bat erakusten da. Lipidoak banatzeko lehenengo TLC banaketa-kromatografikoa erabili eta errebelatutako xafla erakusten da. Xafla horretatik kolesteroleko esterrak (CE) eta kolesterol askea (FC) ez dira MALDI matrize hau erabilita detektatzen, eta beraz, eskaneatzeko geometriatik kanpo utzi dira. Horrela, 8. irudian urdinez markatutako eta handitutako eremua bakarrik eskaneatu da. TLC xaflan seinalatutako eremuak $30 \times 5 \mathrm{~mm}^{2}$ ditu eta $200 \mu \mathrm{m}$-ko espazio-bereizmena erabili da, eta beraz, 3.750 espektro lortu dira eskaneatutako TLC isurbide bakoitzeko.

9. irudiak, erauzkin lipidikoko TLC-MS esperimentuaren osagai nagusizko analisiaren irudia erakusten du. Kolore bakoitzak lipido espezie bat adierazten du. Bere eskuinaldean, errebelatutako TLC xafla batean erakusten da MALDI bidez eskaneatutako handiagotzea eta orban bakoitzaren esleipena jarrita agertzen da. Beste irudi guztiak orban bakoitzean PCA analisiari dagozkio, hau da, antzeko espektroak elkarrekin jartzen dira eta horregatik, orban bakoitza bereiz daiteke eta bai orban horretan dauden espezieak ere. 

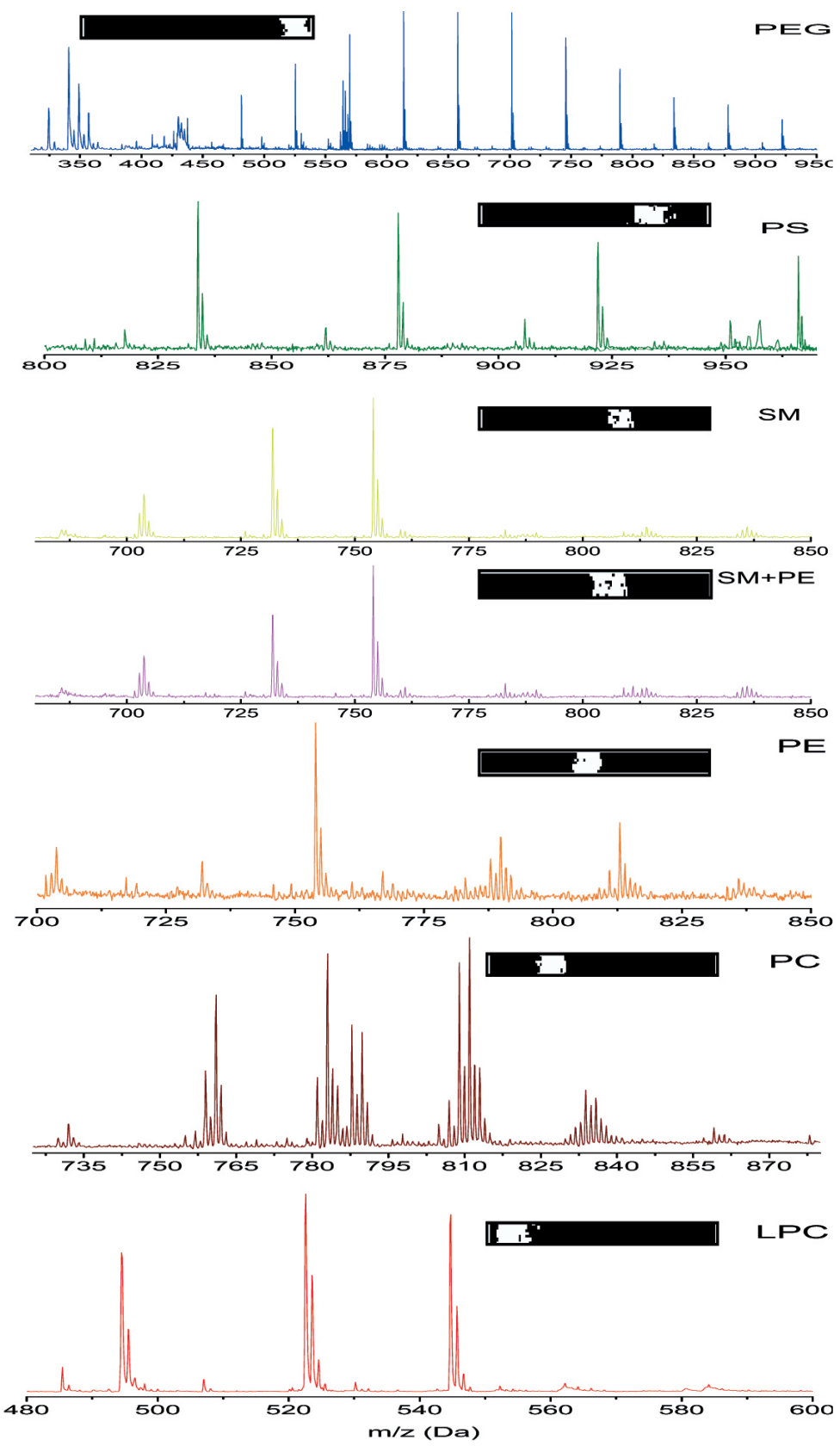

7. irudia. Automatikoki identifikatutako azalerak softwarraren bitartez eta PCA analisia erabilita. Azpian, TLC kaleetako patroi lipidikoen azalera bakoitzari dagokion batezbesteko espektroa. 

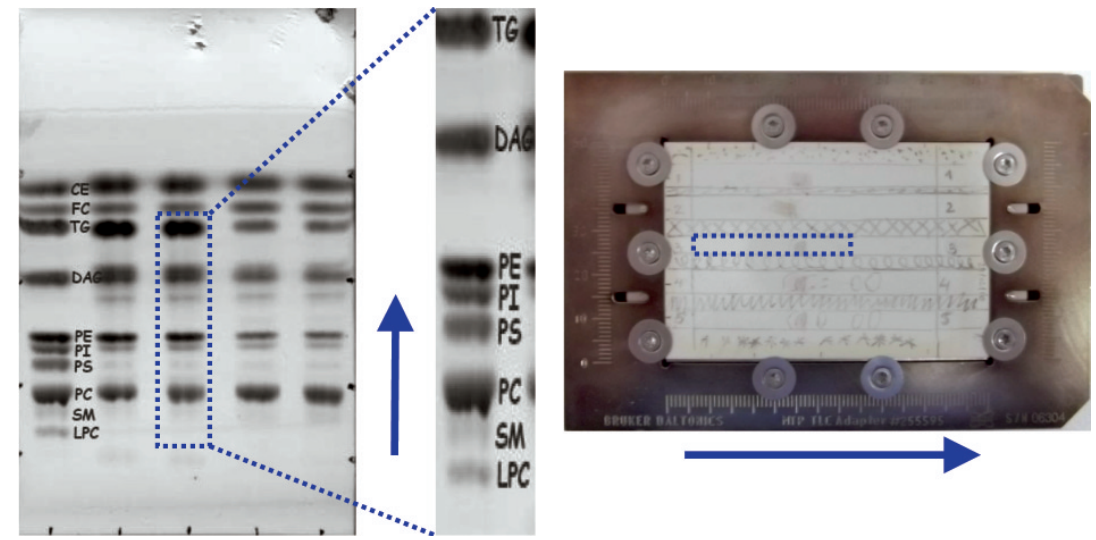

8. irudia. Errebelatutako bost isurbideko TLC xafla, marraskari-burmuineko lipido-erauzkinaren banaketari dagokio. Urdinez markatutako laukiak eskaneatutako eta handitutako eremua seinalatzen du. Eskuinaldean, TLC xafla bera agertzen da metalezko euskarrian. Xafla $90^{\circ}$ eskuinera bira emanda dago (bestearekin alderatuta) eta MBT-z estalita. Arkatzez markatuta agertzen dira TLC isurbideak agertzen dira. Urdinez margotutako geziek, TLC xaflan erabili den disolbatzaile desberdinen eluzioaren norabidea adierazten dute.
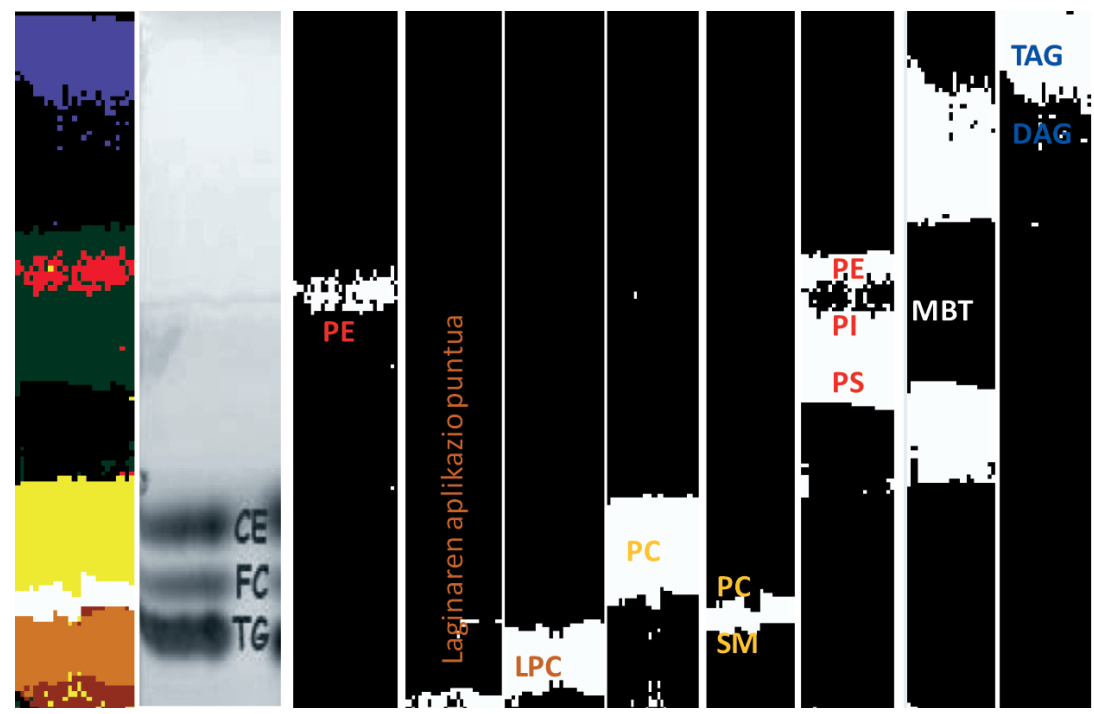

9. irudia. (Ezkerra, 1. zutabea) Marraskari-burmuineko lipido-erauzkinaren banaketaren irudia PCA erabilita. (2. zutabea) MALDI bidez eskaneatutako handiagotzea errebelatutako TLC xafla batean, eta orban bakoitzaren esleipena. Beste zutabe guztietan PCA analisia ageri da dagokion orban bakoitzean. 

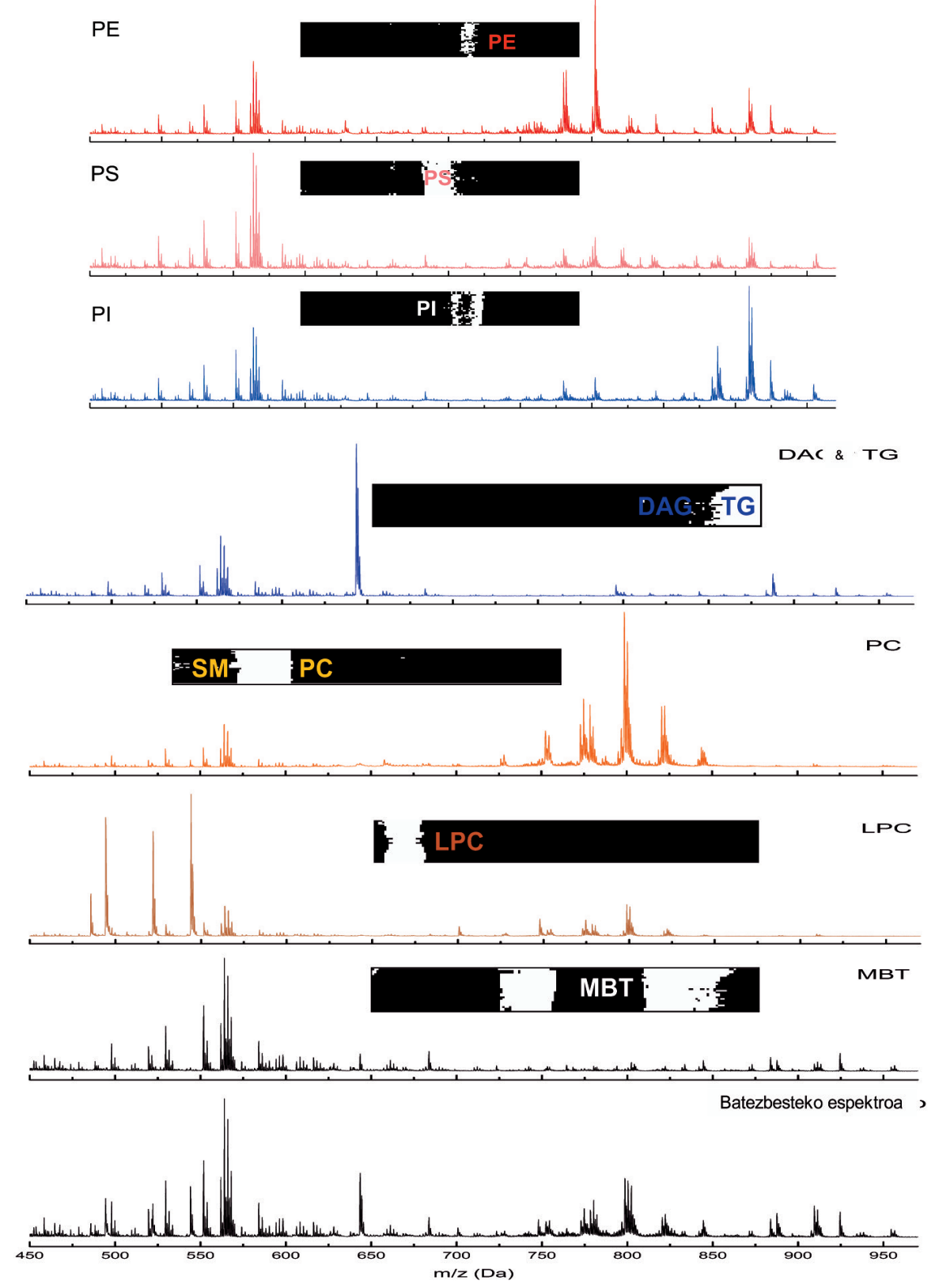

10. irudia. TLC-MS-n lortutako espektroen konparazioa. TLC isurbide osoaren batezbesteko espektroa (behean); lipidoak agertzen ez diren batezbesteko espektroa (MBT espektroa); eta PCA-ren bitartez automatikoki identifikatutako orban desberdinetan lortutako batezbesteko espektroak (beste espektro guztiak). 


\section{ONDORIOAK}

Esan dezakegu lan honen emaitzak bat datozela beste talde batzuen emaitzekin. TLC kromatografia teknika eta MALDI masa-espektrometria akopla daitezke, eta horrela informazio baliagarria lortzen da, zehazki lipidoak aztertzeko.

Alde batetik, egiaztatu da TLC-IMS egiteko probatu diren matrizeetatik, MBT dela matrize egokiena. Beste alde batetik, erakutsi da TLC xafla matrizez asetutako disoluzio batean murgiltzea dela prestakuntza egokiena. Bestalde, eremu baten batezbesteko espektroa erakusten da software baten bitartez, hau da, orban bakoitzaren batezbesteko espektroa lipido espezie berdinekin. Era honetan, espektroen seinaleak hobetu egiten dira eta lipido espezie gehiago detektatzen dira.

Bi teknika hauen konbinazioa bestelako biomolekulen detekziorako erabil daiteke eta askotan produktu berrien sintesian lortzen diren orban desberdin eta ezezagunen karakterizaziorako ere erabil daiteke.

\section{ESKER ONAK}

Lan hau «Biomolekulen eta farmakoen detekzioa MALDI-IMS Masaespektrometria erabilita» doktore-tesiaren atal batzuetan oinarrituta dago. Kimika Fisikoa sailean Espektroskopia Molekularraren taldean gauzatu da, Dr. José Andrés Fernández eta Dr. Rafael Rodríguez-Puertas ikertzaileen zuzendaritzapean. Euskal Herriko Unibertsitateari (UPV/EHU) doktore-tesia aurrera eraman ahal izateko emandako diru-laguntza eskertzen diot.

\section{BIBLIOGRAFIA}

[1] FUCHS, B.; NIMPTSCH, A.; SUSS, R.; SCHILLER, J. 2008. «Analysis of Brain Lipids by Directly Coupled Matrix-Assisted Laser Desorption Ionization Time-of-Flight Mass Spectrometry and High-Performance Thin-Layer Chromatography». Journal of Aoac International, 91, 1227-1236.

[2] GOTO-INOUE, N.; HAYASAKA, T.; TAKI, T.; GONZALEZ, T.V.; SETOU, M. 2009. «A new lipidomics approach by thin-layer chromatographyblot-matrix-assisted laser desorption/ionization imaging mass spectrometry for analyzing detailed patterns of phospholipid molecular species». Journal of Chromatography A, 1216, 7096-7101.

[3] FUCHS, B.; SCHILLER, J.; SUESS, R.; ZSCHARNACK, M.; BADER, A.; MUELLER, P.; SCHUERENBERG, M.; BECKER, M.; SUCKAU, D. 2008. «Analysis of stem cell lipids by offline HPTLC-MALDI-TOF MS». Analytical and Bioanalytical Chemistry, 392, 849-860. 
[4] KALUZNY, M.A.; DUNCAN, L.A.; MERRITT, M.V.; EPPS, D.E. 1985. «Rapid separation of lipid classes in high yield and purity using bonded phase columns». Journal of Lipid Research, 26, 135-140.

[5] AGREN, J.J.; JULKUNEN, A.; PENTILLA, I. 1992. «Rapid separation of serum lipids for fatty acid analysis by a single aminopropyl column». Journal of Lipid Research, 33, 1871-1876.

[6] STEWART, J.C.M. 1980. «Colorimetric determination of phospholipids with ammonium ferrothiocyanate». Analytical Biochemistry, 104, 10-14.

[7] RAHEJA, R.K.; KAUR, C.; SINGH, A.; BHATIA, I.S. 1973. «New colorimetric method for the quantitative estimation of phospholipids without acid digestion». Journal of Lipid Research, 14, 695-697.

[8] GAMBLE, W.; VAUGHAN, M.; KRTUH, H.S.; AVIGAN, J. 1978. «Procedure for determination of free and total cholesteroil in micro- or nanogram amounts suitable for studies with cultured cells». Journal of Lipid Research, 19, 1068-1070.

[9] ALMOG, R.; ANDERSON-SAMSONOFF, C.; BERNS, D.S.; SAULSBERY, R.A. 1990. «Methodology for determination of phospholipids». Analytical Biochemistry, 188, 237-242.

[10] ACKMAN, R.G. 1981. «Flame ionisation detection applied to thin-layer chromatography on coated quartz rods». Methods Enzymol. 72, 205-252.

[11] BEAUMELLE, B.D.; VIAL, H.J. 1986. «Total cholesterol, fatty acids, and plasmalogens can be reliably quantitated quired for fatty acid analysis by gas-liquid chromatography». Analytical Biochemistry, 155, 346-351.

[12] CHRISTIE, W.W. 1985. «Rapid separation and quantification of lipid classes by high performance liquid chromatography and mass (light scattering) detection». Journal of Lipid Research, 26, 507-512.

[13] HAMILTON, J.G.; COMAI, K. 1988. «Separation of neutral lipid, free fatty acid and phospholipid classes by normal phase high-performance liquid chromatography». Lipids, 23, 1150-1153.

[14] MANGOLD, H.K. 1961. «Thin layer Chromatography of lipids ». Journal of the American Oil Chemists Society, 38, 708-727

[15] RUIZ, J.I.; OCHOA, B. 1997. «Quantification in the subnanomolar range of phospholipids and neutral lipids by monodimensional thin-layer chromatography and image analysis». Journal of Lipid Research, 38, 1482-1489.

[16] BITMAN, J.; WOOD, D.L. 1982. «An improved copper reagent for quantitative densitometric thin-layer chromatography of lipids». Journal of Liquid Chromatography, 5, 1155-1162.

[17] FERNANDEZ, J.A.; OCHOA, B.; FRESNEDO, O.; GIRALT, M.T.; RODRIGUEZ-PUERTAS, R. 2011. «Matriz-assisted laser desorption ionization imaging mass spectrometry in lipidomics». Analytical and Bioanalytical Chemistry, 401, 29-51. 
[18] VELOSO, A.; FERNÁNDEZ, R.; ASTIGARRAGA, E.; BARREDAGOMEZ, G.; MANUEL, I.; GIRALT, M.T.; FERRER, I.; OCHOA, B.; RODRIGUEZ-PUERTAS, R.; FERNANDEZ, J.A. 2011. «Distribution of Lipids in human brain». Analytical and Bioanalytical Chemistry, 401, 29.

[19] VELOSO, A.; ASTIGARRAGA, E.; BARREDA-GOMEZ, G.; MANUEL, I.; FERRER, I.; GIRALT, M.T.; OCHOA, B.; FRESNEDO, O.; RODRIGUEZ-PUERTAS, R.; FERNANDEZ, J.A. 2011. «Anatomical distribution of lipids in human brain cortex by imaging mass spectrometry». Journal of American Society for Mass Spectrometry, 22, 329.

[20] FUCHS, B.; BISCHOFF, A.; SUSS, R.; TEUBER, K.; SCHURENBERG, M.; SUCKAU, D.; SCHILLER, J. 2009. «Phosphatidylcholines and -ethanolamines can be easily mistaken in phospholipid mixtures: a negative ion MALDI-TOF MS study with 9-aminoacridine as matrix and egg yolk as selected example». Analytical and Bioanalytical Chemistry, 395 (8), 2479. 